\title{
Commentary \\ A trauma shake-up: Are NZ graduates being prepared for the real world?
}

\begin{abstract}
ABSTRACI
Young journalists today are highly likely to cover traumatic incidents early in their careers, with many confronting trauma day to day. This pressure is exacerbated in the current economic climate and fast-paced changing world of journalism. New Zealand graduates are no exception. Few are prepared by their journalism schools to deal with trauma. Should they be taught these skills during their training or should they wait until they are in the workplace? Research has recommended the former for at least two decades. Perhaps it is time New Zealand caught up with many American and Australian journalism schools and introduced changes to the journalism curricula to ensure graduates are equipped with skills to recognise signs of stress in themselves as well as victims. The workplace can underpin this training with recognition and support, which has been shown to improve productivity and resilience.
\end{abstract}

Keywords: journalism education, graduates, resilience, trauma, trauma training, graduates, journalism education, workplace

\section{LYN BARNES}

\section{AUT University, Auckland}

7 HE CHRISTCHURCH earthquake in February 2010 shook up the New Zealand media in more ways than one. Surprisingly, a number of journalists who covered the devastating aftermath, in which 185 people lost their lives, were recent graduates. But it is not only natural disasters that are a concern for inexperienced journalists. As one graduate put it, 'What about all the run-of-the-mill trauma we deal with day to day?' 
The move towards tabloidisation, where violent and traumatic events have increasingly become news staples (Cote \& Simpson, 2006), begs the ethical question: As journalism teachers, are we letting our students down? Research shows that the journalists most at risk of stress are graduates (Simpson \& Bogg, 1999; Johnson 1999; Maxson 2000; Rees 2007; Young 2011). Johnson (1999) found that most news journalists encountered death or violence early in their careers - and it was often inexperienced reporters who were assigned to interview family members following a fatality (Maxson, 2000). This issue becomes more important for young journalists who confront other daily pressures with the media industry in a state of flux, the demands of round-the-clock news, concentrated media ownership, commercial pressures, job scarcity and weak unions (Berrington \& Jemphrey, 2003).

A study in 2007 by Dworznik and Grubb confirmed that it is often the youngest reporters who are sent to accident scenes, and, although little can be done to prevent post-traumatic stress or its symptoms, training can help lessen the blow of a traumatic experience. While much research has looked at war correspondents and trauma, little has focused on journalists at home, doing their everyday jobs. Yet it is now established that trauma has a cumulative effect (Rees, 2007; Keats \& Buchanan, 2009). That cumulative effect can start to affect journalists' relationships outside the workplace (Rees, 2007). Keats and Buchanan also showed that a failure to understand how journalists reacted to trauma - and who were given no help to deal with it — affected their work, their health and their relationships. Further research suggests that time off work is one of the best cures for stress and, that if it is provided for early on, journalists often become more resilient. Dealing with the problem early on then becomes a win-win for employee and employer (Newman, 2012).

The study of trauma is a relatively new area of research, which began in the United States after the 1995 Oklahoma City bombing and gained momentum following the Columbine shootings. The first study to show a link between journalism and trauma was after a group of reporters witnessed an execution in the United States (Freinkel, Koopman \& Spiegel, 1994). Some of them experienced similar symptoms to post-traumatic stress disorder (PSTD), such as emotional numbing and flashbacks. The American Psychological Association (APA) introduced this term after the Vietnam War, when veterans displayed specific patterns of psychological and physical symptoms, including hallucinations. In 1994, the APA added acute stress disorder (ASD) to its diagnostic criteria. This clearly differentiated the two conditions: PTSD 
describes a pattern of symptoms that continue for more than a month, whereas ASD is used to describe similar symptoms which last for more than two days and less than a month.

By 2000, researchers confirmed that journalists also displayed symptoms of trauma (Simpson \& Boggs, 1999) but they were yet to look at the effects or what might be done about it.

Although mass murders such as Columbine and Dunblane may be rare, or terrorist attacks such as the 9/11 terrorist attack on New York are unknown in Australasia, New Zealand has its own disasters and tragedies. New Zealand statistics on child abuse, teenage suicide and road accidents rank among the highest in the world. A 2003 The United Nations Children's Fund (UNICEF) report on child maltreatment in the 1990s ranked New Zealand third worst of 27 OECD countries. Since then, the number of reports received by Child, Youth and Family (CYF) relating to children or youth being abused or neglected in New Zealand has doubled. The number of CYF findings of abuse (physical, sexual, emotional) and neglect has also more than doubled over the seven years from 2003-4 to 2009-10. Figures from the Ministry of Social Development recorded between 2002 and 2007 showed New Zealand had the second highest male youth (15-24 years) suicide death rate (after Finland), and the second highest female youth suicide death rate (after Japan). New Zealand also had the highest rate of deaths in car accidents for 15 to 17-year-olds, with 15.0 deaths per 100,000, more than double the Organisation for Economic Co-operation and Development (OECD) median of 7.3.

This then begs the question: Who should be responsible for trauma training? Should it be taught in journalism schools or in the workplace? Maxson's study (2000) found that all graduates saw trauma training as a worthwhile exercise in order to address trauma victims appropriately. Other studies since (Rees, 2007; Keats \& Buchanan, 2009) concluded that appropriate training can not only help to detect problems early but also assists journalists to recover.

An informal survey conducted in 2011 indicated that of the 10 journalism training schools in New Zealand registered with the NZ Journalism Training Organisation (NZJTO), only two spent more than an hour during their programmes (which ranged from one to three years) teaching skills to deal with grief and trauma. Some of the responses suggested a desire to include trauma training in the curriculum but it was not a priority, and was not included in the current unit standards. 
Most journalism schools in New Zealand teach unit standards, or content approved by the industry-training organisation, the NZJTO. Unit standards cover the skills needed by journalists but the skills of dealing with trauma are not included. Anecdotal comments from the informal survey suggested that covering the full curricula, coupled with increasing time pressures, meant journalism teachers simply could not include trauma training.

Since the early 1990s trauma training has been introduced into a number of journalism schools (Ricchiardi, 1999) in the United States, the United Kingdom and Australia. The NZJTO discussed the issue of introducing trauma training at its annual general meeting in 2011 but as of November 2012 there had been no change.

While most police, paramedics and fire service personnel are routinely debriefed after attending a disaster, as a rule, journalists are not. Yet they are recognised as what has become termed 'first responders' and are often exposed to unpleasant and gory details. Basic skills for journalism students could include how to assess any risk to themselves and, secondly, how to deal with a potentially traumatising situation, be it an accident, suicide or murder. Thirdly, there are lessons to be learned about appropriate questioning when dealing with victims as well as fact checking, to avoid revictimising the victims.

Trauma lurks in all sorts of unforeseen places (Rees, 2007) and can be secondary (Keats \& Buchanan, 2009), that is, as a result of observing other people suffering. Court reporters, for example, may spend hours listening to detailed accounts of cruelty and abuse, casual or premeditated. Particularly relevant for New Zealand journalists is the research by Simpson and Coté (2000), who investigated court cases involving child murders. They found that human-instigated violence caused the most severe post-traumatic reactions, whereas man-made accidents and natural disasters ranked second and third, respectively.

Young (2011) is adamant that curriculum change is needed:

Journalism schools spend a lot of time teaching leads, interviewing skills, video editing and database searches. It's imperative educators take time to talk about the emotional aspects of telling the world's worst stories.

Acknowledgement can't be the only step. Otherwise, journalism instructors and media managers are letting their reporters become the frogs that slowly boil to death. (Young, 2011, p. 16) 
The editor of the New Zealand Herald told AUT journalism students in 2012 that 'Whatever can kill, will make the front page'. Death sells newspapers and trauma is cheap. And it is not only news journalists who are potentially at risk; it was mostly fashion reporters who were the first to respond to a call for journalists to cover the 9/11 attacks as it was New York Fashion Week (Newman \& Nelson, 2012).

Is it fair that editors should be responsible for preparing graduates to cover trauma? Is this realistic in increasingly busy newsrooms, where editors currently work with restricted staff numbers following worldwide reductions in newspaper revenue and who sometimes have to rely on freelancers? This then introduces the issue of freelance writers who often work in isolation, and who do not have the direct support of an editor or peers. It also becomes a concern if training is left to newsroom managers.

Then there is the stigma of admitting stress: journalists have often been reluctant to acknowledge or admit their work might be taking an emotional toll on them because it might be construed as a sign of weakness and few editors have acknowledged it (Simpson \& Boggs, 1999; Rees, 2007; Keats \& Buchanan, 2009). In 1999 Simpson and Boggs called on news organisations to be more empathetic and talk openly about traumatic stress, as well as search for effective solutions to help journalists recover from what they term the wounds of their work. Only 30 percent of respondents in their study said the employer helped them or others to handle stress. Most mentioned that counselling was available but some also stated that nobody appeared to take advantage of it.

A decade later, Beam and Spratt (2009) found the notion that news workers can be vulnerable to trauma has 'only recently begun to enter the dialogue about sound newsroom management' (p. 421). They also found that management support could be critical in helping journalists cope effectively, and that support could also improve job satisfaction and morale. Young (2011) cautioned that failing to equip young people for their jobs might also cause the talented ones to leave the profession because no one explained that it was acceptable to feel emotional.

Lack of communication or acknowledgement that a journalist had suffered trauma left some feeling isolated, lonely, and devastated (Beam \& Spratt, 2009). Their study of 400 American news people showed that only about one in five journalists felt very well prepared to deal with victims of violence or traumatic events, and one in three said they were not well prepared or not 
prepared at all. These results could be useful in all newsrooms. As Beam and Spratt suggested:

If training is called for, managers could use that occasion to sensitise journalists to their own potential vulnerability to emotional distress; to reaffirm support for employees who experience emotional reactions to tragedies; and to provide employees with the professional skills that they need to do their jobs effectively and sensitively. (Beam \& Spratt, 2009, p. 433)

These concerns are compounded by the fact that journalists are confronting a changing ethical landscape (Kay, Reilly, Amend \& Kyle, 2011). Their study found that many journalists felt pressured to act in ways they did not feel was ethical, to obtain a story. Berrington and Jemphrey (2003) discussed the lack of protection for journalists who were asked to carry out death knocks immediately after a tragedy, who, if they were reluctant, or refused, were informed someone else would cover the story. Kay et al discussed the double bind which many journalists found themselves in, dealing with the public's appetite for sensationalism and directives from editors to get a story. On one hand, they had people accusing them of being insensitive and invading their privacy, yet they clamoured for juicy tidbits of people's lives and tragedy (p. 447).

The issue of trauma training will hopefully make it back onto the NZJTO agenda soon. Dart Asia Pacific held its first retreat weekend in August 2012. The Dart Center for Journalism and Trauma, which is based at the Columbia University Graduate School of Journalism, is dedicated to informed, innovative and ethical news reporting on violence, conflict and tragedy (Dart Centre Asia Pacific is based in Melbourne.) The journalists, editors, cameramen and photographers who attended the inaugural retreat agreed unanimously to support any moves to improve trauma training in New Zealand. Many have since become vocal in their support for further such retreats and young journalists are developing networks of support to advocate for change. They are beginning to voice their concerns, many following the now right-of-passage 'death knock' experience, aware that they need more skills to deal with raw emotions and traumatised people. Momentum is also building among newsroom staff who have ready access to support material, including handouts and videos, available free on the Dart Centre website. 
The fact that more content in the New Zealand media involves trauma of some sort, whether it is a drowning, a car accident or a child abuse court case, a violent attack or murder, is a compelling reason to readdress this issue. Add to that, the groundswell and the fact that the turnover rate of young journalists in newsrooms is becoming a major concern for employers. Fairfax (NZ) management has recently acknowledged the need for more support for work-related stress as part of its health and safety programme, outside and inside the office. The company is also considering trauma training programmes in its newsrooms, using 'teachable moments' and peer support programmes. Fairfax (NZ) acknowledges that trauma training is not adequate in journalism schools in New Zealand and accepts it needs to address the issue of staff turnover and the negative effects trauma coverage can have on staff.

Considering the NZJTO advises the NZQA on unit standards and what should be taught to journalism students, it would be advantageous to capitalise on this important link between journalism training and industry. Ideally, once the essential skills are identified - for example, coping strategies in difficult situations and self-care recognition skills - then the next step is to work out how at least the fundamental aspects can be integrated into the current journalism courses. Then further skills can be introduced in the workplace to staircase learning through regular workshops and residential courses.

The outcome of the first court case involving trauma in Australia could see a million-dollar payout if the owners of The Age newspaper are found guilty of breaching its duty of care by failing to provide a safe workplace. The plaintiff told the Melbourne court in November 2012 that her life began to unravel after she covered the first anniversary of the 2002 Bali bombings. The formerly vibrant Walkley Award-winning photojournalist had worked on a series of 21 stories on the anniversary of the Bali bombings and now suffers from post-traumatic stress, anxiety and extreme depression.

Could such a case be the final jolt needed to shake the New Zealand media industry out of its complacency or will it continue, knowing that accident compensation in New Zealand protects employers from being sued? Still, there is legislation under the Health and Safety in Employment Act 1991 to prevent harm to all people at work, and others in, or in the vicinity of, places of work, and stress and trauma cannot be ignored.

Now that Fairfax has accepted the mandate to improve trauma training, the next step is to ensure that what is introduced into the newsrooms is effective and that there is consistency and continuity in trauma training 
throughout the industry — and hopefully another decade does not slip by before changes are made.

\section{References}

Berrington, E., \& Jemphrey, A. (2003). Pressure on the press: Reflections on reporting tragedy. Journalism, 4(2) 225-248. doi: 10.1177146488490342005

Cote, W., \& Simpson, R. (2006). Covering violence: A guide to ethical reporting about victims and trauma [2nd Ed.]. New York, NY: Columbia University Press.

Dworznik, G., \& Grubb, M. (2007). Preparing for the worst: Making a case for trauma training in the journalism classrooom. Journalism \& Mass Communication Educator, 62(2), 190-210. doi: 1177/107769580706200206

Hollings, J. (2005). Reporting the Asian tsunami: Ethical issues. Pacific Journalism Review, 11(2), 151-167. Retrieved on March 18, 2013, from: www.pjreview.info/ articles/reporting-asian-tsunami-ethical-issues-830

Informal survey (July, 2001) Trauma teaching in New Zealand. Responses from eight of the ten members of JEANZ. Auckland: Journalism Education Association of New Zealand Incorporated.

Johnson, M. (1999). Aftershock: Journalists and trauma. The Quill, 87(9), 14.

Keats, P., \& Buchanan, M. (2009). Addressing the effects of assignment stress injury. Journalism Practice, 3(2), 162-177. doi:10.1080/17512780802681199

Maxson, J. (2000). Training journalism students to deal with trauma. Journalism \& Mass Communication Educator, 55(1), 79-86.

Peacock, C. (Producer). (October 14, 2012 ) Mediawatch: Special edition. Retrieved on March 12, 2013, from http://podcast.radionz.co.nz/mwatch/ mwatch-20121014-0908 mediawatch_for_14_october_2012-048.mp3

Newman, E., \& Nelson, S. (2012). Reporting on resilience and recovery in the face of disaster and crime: Research and training implications. Australian Journalism Review, 34(1), 1732.

Rees, G. (2007). Weathering the trauma storms. British Journalism Review, 18(2), 65-70. doi: 10.1177/0956474807080949

Rentschler, C. A. Trauma training and their reparative work of journalism. Cultural Studies, 24(4), 447-477

Simpson, R., \& Boggs, J. (1999, Spring). An exploratory study of traumatic stress among newspaper journalists. Journalism \& Communication Monographs, 1(1), $1-26$.

Young, N. (2011). Dealing with trauma begins in school. The Quill, 99(3), 16.

Lyn Barnes is a senior lecturer in journalism at AUT University, New Zealand. Her initial research into trauma training in New Zealand journalism schools helped her to win a fellowship to the Dart Center for Journalism and Trauma at Columbia University, New York, in June 2012.

lyn.barnes@aut.ac.nz 